\title{
Phytochemical Screening and in-Vitro Antimicrobial Activities of the Leaf Extract of Acanthospermum hispidum DC (Asteraceae)
}

\author{
Ali Abubakar ${ }^{1}$, Olufunke Adebola Sodipo ${ }^{2}$, Ifan Zaher Khan ${ }^{1}$, Mohammed Baba Fugu ${ }^{1}$, \\ Umar Tanko Mamza ${ }^{1} \&$ Isa Adamu Gulani ${ }^{3}$ \\ ${ }^{1}$ Department of Chemistry, University of Maiduguri, Maiduguri, Nigeria \\ ${ }^{2}$ Department of Clinical Pharmacology and Therapeutics, College of Medical Sciences, University of Maiduguri, \\ Maiduguri, Nigeria \\ ${ }^{3}$ Department of Veterinary Physiology, Pharmacology and Biochemistry, Faculty of Veterinary Medicine, \\ University of Maiduguri, PMaiduguri, Nigeria \\ Correspondence: Ali Abubakar, Department of Chemistry, University of Maiduguri, Maiduguri, Nigeria. Tel: \\ 234-(0)802-234-6843. E-mail: abubakarali799@yahoo.com
}

Received: March 9, 2014 Accepted: July 13, 2015 Online Published: July 15, 2015

doi:10.5539/jps.v4n2p66 URL: http://dx.doi.org/10.5539/jps.v4n2p66

\begin{abstract}
The study into the chemical contents and in-vitro antimicrobial activities of the methanolic leaf extract of Acanthospermum hispidum were carried out. The extract was evaluated for its antibacterial activity against four Gram positive (Staphylococcus aureus, Streptococcus pyogenes, Corynebacteria specie and Bacillus subtilis) and four Gram negative bacteria (Salmonella typhi, Klebsiella phumoniae, Pseudomonas aeruginosa and Escherichia coli). The fungal strains used were Aspergilus niger, Penicillium sp. and Candida albicans. The sensitive microorganisms (Conynebacteria sp., Pseudomonas aeragunosa, Klebsiella pneumoniae, Bacillus subtilis and Staphylococcus aureus) had zones of inhibition ranging from $12.20 \pm 1.06 \mathrm{~mm}$ to $24.00 \pm 1.00 \mathrm{~mm}$ at $100 \mathrm{mg} / \mathrm{ml}$, while the standard drug (tetracycline $250 \mathrm{mg}$ ) had zones of inhibition in the range $20.27 \pm 0.64 \mathrm{~mm}$ to $27.23 \pm$ $0.68 \mathrm{~mm}$ against all the microorganisms tested in this study. The MIC/MBC against the tested organisms ranged from $25 \mathrm{mg} / \mathrm{ml}$ to $50 \mathrm{mg} / \mathrm{ml}$ and $50 \mathrm{mg} / \mathrm{ml}$ to $100 \mathrm{mg} / \mathrm{ml}$ respectively. The results obtained from this study revealed that the leaf extract of Acanthospermum hispidum possesses antibacterial activity against some pathogenic microorganisms tested. The study confirmed the use of the leaf of Acanthospermum hispidum in some parts of Northern Nigeria as a remedy against diarrhoea, dysentery and other related diseases. In view of the reported uses of this plant, the present study investigated the antimicrobial effect of the methanol extract of $A$. hispidum on some Gram positive, Gram negative and some fungal species.
\end{abstract}

Therefore, this study validates the medicinal use of Acanthospermum hispidum tradicinally in some parts of Northern Nigeria.

Key words: Acanthospermum hispidum, phytochemical screening, antimicrobial, methanolic extract

\section{Introduction}

Acanthospermum hispidum (DC) (Bristly starbur) from Asteraceae family is found in the tropical and sub-tropical temperate regions of the world. In Nigeria, the plant is common as a weed along the roads and in moist habitats and is reported to have various medicinal values (Smith, 2002). A. hispidum can be potential sources of useful drugs (Faleye et al., 2012). Acanthospermum hispidum is adapted to a wide range of soil and climatic conditions. It is particularly adapted to light textured soil but also grows well in heavy textured one. It is commonly found in cultivated upland crops, roadsides, pastures, waste area, around corrals, along railroads and cattle trails. Both seed and leaves contain phenolic acids that are allelophatic to other plants (Holm et al., 1997). It is found in a wide range of habitats, commonly on roadsides, disturbed areas and around settlements. It is known to invade pastures and out-compete more desirable native species. It is also a weed of crops and a serious contaminant of wool (Smith, 2002). Sub-inhibitory concentrations of A. hispidum $(5 \mathrm{mg} / \mathrm{ml})$ enhanced the activity of amoxicillin against Staph. aureus and B. subtilis but reduced slightly the activity against Kl. pneumoniae. Combining ciprofloxacin with the sub-inhibitory concentrations $(5 \mathrm{mg} / \mathrm{ml})$ of A. hispidum extract modulated the resistance of all the organisms to ciprofloxacin. The resistance modulatory activity of the extracts 
on amoxicillin and ciprofloxacin is more pronounced with Gram positive organisms than Gram negative organisms (Adu et al., 2011). Bioactivity-directed purification of the leaf of A. hispidum using anti-trichomonal assay yielded subfractions $\mathrm{C}_{6}$ and $\mathrm{C}_{7}$ which had activity comparable to metronidazole, the positive control and had better activity than the mother ethyl acetate extract. The study further showed the potential usefulness of $A$. hispidum in treating protozal infections (Deepa et al., 2004).

The leaves and stems of Acanthospermum hispidium were extracted with distilled ethanol using cold extraction and concentrated using a rotary evaporator at $37^{\circ} \mathrm{C}$. The crude extract was partitioned successively using hexane, benzene and methanol. Fractions 19, 20 and 21 purified on Sephadex LH-20 gave a compound elucidated to be 1, 3, 6, 8-tetrahydroxyl-9-anthracene carbonaldehyde, using the state-ofart tools of spectrometry. The results of the antimicrobial test on the isolated compound show activity against $P$. mirabilis, B. subtilis, $P$. aeruginosa, $C$. albican, S. typhi and B. cereus at minimum inhibitory concentration (MIC) value of 100 ppm Olajide et al., (2014). Early workers have reported the use of the stem bark for medicinal purposes (Chakraborty et al., 2012). Acanthospermum hispidum plant is important for its medicinal properties. In Nigeria, from information available from the indigenous traditional healers, the crushed herb is used in the form of a paste to treat skin ailments and the leaf juice is taken orally to relieve fevers (Mshana et al., 2000).

\section{Materials and Methods}

\subsection{Sample Collection and Identification}

Fresh samples of the leaves of Acanthospermum hispidum were collected from Uvaha village, Gwoza Local Government Area, of Borno State in November, 2012. The plant was identified and authenticated by a plant Taxonomist Prof. S.S. Sanusi, in the Department of Biological Sciences, University of Maiduguri. A voucher specimen No. Chem/09/01 was deposited in the Research Laboratory, Department of Chemistry. The leaves were cleaned, air-dried under shade for seven (7) days, then pulverised to powder and coded "plant material".

\subsection{Extraction of Plant Material}

The air-dried powdered plant material (1000 g) was extracted exhaustively with $85 \%$ methanol using a Soxhlet apparatus as described by Evans (2002). The methanolic extractobtained was concentrated to dryness at $45^{\circ} \mathrm{C}$ on a water bath and coded "CMLE" Crude methanolic leaf extract. About $200 \mathrm{~g}$ of the CMLE concentrate were subjected to preliminary phytochemical screening and in-vitro antimicrobial susceptibility test while the MIC and MBC determined accordingly.

\subsection{Qualitative Phytochemical Screening}

The crude methanolic leaf extract "CMLE" of A. hispidum was subjected to qualitative phytochemical screening for identification of the various classes of active chemical constituents such as flavonoids, alkaloids, sterols, terpenes, saponins, tannins as methods described by the Harbone (1973), Awe and Sodipo (2001), Evans (2002); Sofowora (2008).

\section{Atimicrobial Studies}

\subsection{Test Microorganisms}

A number of microorganisms consisting of both Gram positiveand Gram negative (-ve) bacteria were used. The Gram positive (+ve) organisms used were Streptococcus faecalis, Staphylococcus aureus, Corynbacterium spp, and Bacillus cereus, while the Gram negative ones were: Escherichia coli, Salmonella typhi, Klebsiella pneumoniae and Pseudomonas aeruginosa and some fungi species such as: Candida albicans Aspergillus niger and Penicillium species were also used. The microorganisms were obtained from the University of Maiduguri Teaching Hospital, Maiduguri, (UMTH) Nigeria.

\subsection{In vitro Disc Antibacterial Activity of Methanolic Extract of Leaf}

The in vitro disc diffusion method was used to test for antibacterial activity of the extract as described by Cheesbrough (2004).

\subsection{Preparation of Culture Media}

The culture media used in this study were nutrient agar (Biotec Medical Market, UK) for bacteria and Candida albicans and sabouraud-2\% glucose agar (Merk, Darstadt, Germany) for Penicilium spp. and Aspergillus niger The nutrient agar was prepared according to the manufucturer's specifications (by dissolving $18.5 \mathrm{~g}$ powder in 500 $\mathrm{ml}$ distilled water) and strerilized at $121{ }^{\circ} \mathrm{C}$ for 15 minutes. After autoclaving, the $\mathrm{pH}$ was 7.2-7.4 (Bello, 2002). This was poured in $90 \mathrm{~mm}$ diameter sterile, disposable plastic petri-dishes to a depth of $4 \mathrm{~mm}$ (about $25 \mathrm{ml}$ per plate). Care was taken to pour the plates on a level surface so that depth of the medium would be uniform. The 
plates were dried upside down in an incubator at $37{ }^{\circ} \mathrm{C}$ with their lids opened and inverted so that water would not condensed back in to the agar. The sabouraud- $2 \%$-glucose agar was prepared according to the manufacturer's specification (by dissolving $18.5 \mathrm{~g}$ in $400 \mathrm{ml}$ of distilled water) and sterilized at $121{ }^{\circ} \mathrm{C}$ for 15 minutes. $1 \mathrm{ml}$ each of the different concentrations of the CMLE $(200 \mathrm{mg} / \mathrm{ml}, 400 \mathrm{mg} / \mathrm{ml}, 800 \mathrm{mg} / \mathrm{ml}$ and $1600 \mathrm{mg} / \mathrm{ml})$ was pipette into eight (8) sterile, disposable petri-dishes i.e. 2 plates for each CMLE concentration $25 \mathrm{ml}$ of the sabouraud-2\%-dextrose agar was poured in to the plate, swirled round to mix very well with the CMLE, then allowed to set at low temperature. The other plates were also prepared, but without the CMLE, to act as the control. All the eleven plates were then incubated upside down, with their lides opened at $37{ }^{\circ} \mathrm{C}$ in an incubator to dry (Sodipo et al., 2012)

\subsection{Preparation of Test Organisms}

The microorganisms were propagated and stored on nutrient agar at $4{ }^{\circ} \mathrm{C}$ for 24 hours prior to antimicrobial testing.

\subsection{Preparation of Agar Medium}

Nutrient agar (25 g) was dissolved in one litre (1L) of distilled water in a sterilized conical flask and heated to dissolve by stirring. The prepared medium was tightly corked with aluminium foil and sterilized in an autoclave at $121^{\circ} \mathrm{C}$ at $15 \mathrm{~mm} \mathrm{Hg}$ for 15 minutes. The conical flask was put on a water bath at $55^{\circ} \mathrm{C}$ to cool for 20 minutes. 10 $\mathrm{ml}$ of peptone water was put into a sterile inoculating bottle and sterilized in an autoclave at $121^{\circ} \mathrm{C}$ at $15 \mathrm{~mm} \mathrm{Hg}$ for 15 minutes. Normal saline was prepared by the same process for 30 minutes. The nutrient agar was poured into sterilized petri dishes and allowed to set and dry in an incubator at room temperature (Sodipo et al., 2010).

3.6 Preparation of Discs Containing Graded Concentrations of the CMLE of the Leaves of A. hispidum and Tetracycline Discs

Whatman filter paper No.1 was punched into circular discs (each $6 \mathrm{~mm}$ indiameter), with the aid of an office punch. The discs were then put in a glass petri-dish and sterilized in a hot air oven at $60{ }^{\circ} \mathrm{C}$ for 30 minutes. $1 \mathrm{ml}$ of each of the different concentrations of the extract were put in sterile glass plates and thirteen (13) sterile discs were put in their using sterile forceps to soak the extract, then they were allowed to dry. The discs were checked to be sure that they were not sticking together (Lamikanra, 1999). These CMLE discs were used for the antibacterial tests and that of Candida albicans. One capsule tetracycline $250 \mathrm{gm}$ powder was dissolved in $1 \mathrm{ml}$ distilled water. Sterile discs were then put inside it so as to be soaked with the tetracycline and then left to dry. This gave tetracycline discs of $250 \mathrm{mg} / \mathrm{ml}$ which is equivalent to $2.5 \times 10^{5} \mu \mathrm{g} / \mathrm{ml}$. This concentration of tetracycline disc was prepared because the pilot study revealed that the commercially available tetracycline disc, $50 \mathrm{mg} / \mathrm{ml}$ is too low to be effective on both the bacterial and fungal species under test (Sodipo et al., 2012).

\subsection{Disc Diffusion Antibacterial Selectivity Test}

A stock solution was prepared with sterile distilled water at a concentration of $1 \mathrm{mg} / \mathrm{ml}$. Tetracycline was used as a standard drug. Solutions of different concentrations $(200,400,800,1600,3200,6400 \mathrm{mg} / \mathrm{ml})$ of the methanolic leaf extract and tetracycline $(250 \mathrm{mg} / \mathrm{ml})$ were prepared. Filter papers of $7 \mathrm{~mm}$ in diameter were cut and sterilized for one hour at $160{ }^{\circ} \mathrm{C}$. The paper discs were placed on the prepared solutions to allow for absorption of the solution. The standard discs were allowed to dry in the oven and then placed on the dried surface of the culture plates already inoculated with bacteria (Agar Plates) and left at $37^{\circ} \mathrm{C}$ for incubation. The zones of inhibition were measured after 24 hours (Soodipo, et al., 2010) and recorded if it was greater than 10mm (Vlietinek et al., 1995). 3.8 Disc Diffusion Antifungal Selectivity Test

The antibiotic disc tetracycline $\left(2.5 \times 10^{5} \mu \mathrm{g} / \mathrm{disc}\right)$ were placed on the already prepared sabouraud-2\%-dextrose agar containing graded concentrations of the CMLE ( 8 in all) and the control ( 2 pates). The Penicillium spp. and the Aspergillus niger were then removed from their pure culture with a pair of sterile forceps and placed on the plates so that the organisms could spread on the antibiotic disc and the extract in the plates. The plates were incubated at $25-30^{\circ} \mathrm{C}$ and examined every 2-3 days and kept for four weeks before being considered negative for the fungi (Bello, 2002).

\subsection{Minimum Inhibitory Concentration (MIC)}

MIC can be defined as the lowest concentration where no visible turbidity is observed in the test tube. MIC is a technique employed to know at what concentration the extract can inhibit the microbial activity. MIC was determined using the broth dilution technique Vollekova et al. (2001). The minimum inhibitory concentration was determined from micro-organisms that where sensitive to the extract under study (leaf extract). Equal volume of nutrient broth was dispensed in to tubes (bijou bottles) were known concentrations of the extract diluted at concentration ranging from lowest to highest i.e $12.5 \mathrm{mg} / \mathrm{ml}$ to $200 \mathrm{mg} / \mathrm{ml}$ were prepared. Also $0.2 \mathrm{ml}$ suspension 
of microbial isolates (Pseudomonas aeruginosa and Corynebacteria species) were inoculated to various concentrations.

\subsection{Minimum Bactericidal Concentration (MBC)}

The MBC is defined as the lowest concentration where no bacterial growth is observed (Reuben et al., 2009). MBC was determined by using the broth dilution technique described by Usman et al. (2007) by assaying the test tubes resulting from MIC determinations. A loop of the content of each test tube was inoculated by streaking on a solidified nutrients agar plate incubating at $37{ }^{\circ} \mathrm{C}$ for 18 hours and observed for bacterial growth. The lowest concentration of the subculture with no growth was considered the minimum bactericidal concentration.

\section{Results}

The result of the qualitative phytochemical analysis of methanolic leaf extract is shown in Table 1. The result showed the presence of flavonoids, cardiac glycosides, alkaloids, steroids, terpenes, saponins, carbohydrates and tannins, while anthraquinones and Phlobatanins were absent.

Table 1. Phytochemical analysis of the leaf extract of Acanthospermum hispidum

\begin{tabular}{|c|c|c|c|c|}
\hline S/No & Plant Constituents & Test & Result & Observation \\
\hline 1. & Tannins & Ferric Chloride Test & + & Deep blue black \\
\hline \multirow[t]{2}{*}{2.} & Alkaloids & General test: Dragendorff's Test & + & Orange-red \\
\hline & & Mayer's Test & - & No ppt formed \\
\hline 3. & Saponins & Froth Test & + & Foam formed \\
\hline \multirow[t]{3}{*}{4.} & Cardiac Glycosides & (i) Keller-Killiani’s Test & + & Greenish colour \\
\hline & & (ii) Liebermann-Burchard Test & - & Bluish green \\
\hline & & (iii) Salkowski Test & + & Reddish brown \\
\hline 5. & Steroids & Liebermann-Burchard Test & + & Bluish green \\
\hline \multirow[t]{4}{*}{6.} & Flavonoids & (i) Ferric Chloride Test & + & Bluish green \\
\hline & & (ii) Lead Ethanoate Test & + & Buff color ppt \\
\hline & & (iii) (Shinada's Test) & + & Light pink colour \\
\hline & & (iv) (Sodium Hydroxide Test) & - & Yellow colour \\
\hline 7. & Phlobatanins & Hydrochloric Acid Test & - & No color change \\
\hline \multirow[t]{2}{*}{8.} & Anthroquinones & (i) Free Anthroquinone Test & - & No colour formed \\
\hline & & (ii) Combined Anthroquinone Test & - & No colour formed \\
\hline \multirow[t]{5}{*}{9.} & Carbohydrates & (i) General test (Molish’s Test) & + & Purple colour \\
\hline & & (ii) Monosaccharides (Barfoed's Test) & + & Brick red ppt \\
\hline & & (iii) Free Reducing Sugar & + & Deep brick red \\
\hline & & (iv) Combined Reducing Sugar & + & Deep brick red \\
\hline & & $\begin{array}{l}\text { (v) Ketoses (Resorcinol or Selivanoff's } \\
\text { Test) }\end{array}$ & + & Deep rose colour \\
\hline 10. & Terpenenoids & General Test & + & Pink colour \\
\hline
\end{tabular}

Key: + = present; - = absent (not detected).

In vitro disc diffusion method was used to study the antimicrobial activity of methanol leaf extract. The result of the antimicrobial activity on some bacterial pathogens shows that the extract at various concentrations inhibited the growth of Staphylococcus aureus Conynebacteria sp. Bacillus subtilis, Klebsiella pnumoniae and Pseudomonas aeruginosa were presented in Table 2, but there was no activity against Streptococcus pyogene, E. coli, Salmonella typhii, Candida albican, Aspergillus niger and Pencillium species. Among the sensitive microorganisms, Conynebacteria specie recorded the largest zone of inhibition $(24.00 \pm 1.00 \mathrm{~mm})$ and Staphylococcus aureus recorded the least zone of inhibition $(12.20 \pm 1.06 \mathrm{~mm})$. While other microorganisms such 
as Bacillus cereus, Klebsiella pneumonia and Pseudomonas aeruginosa had $13.00 \pm 1.00 \mathrm{~mm}, 13.33 \pm 1.15 \mathrm{~mm}$ and $18.23 \pm 1.08 \mathrm{~mm}$ zone of inhibition respectively at $1000 \mathrm{mg} / \mathrm{ml}$ concentration. The standard drug (tetracycline $250 \mathrm{mg}$ ) inhibited the growth of the microorganisms tested in this study. The result of the minimum inhibitory concentration and minimum bactericidal concentration (/MIC/MBC) assay are as presented in Table 3 and 4 respectively. They revealed the concentration of the extract which could inhibit the growth of the bacterial species under test (bacteriostatic / bactericidal concentrations) with the values ranges from 25 to $50 \mathrm{mg} / \mathrm{ml}$ and $50 \mathrm{mg} / \mathrm{ml}$ to $100 \mathrm{mg} / \mathrm{ml}$ respectively.

Table 2. In vitro disc antimicrobial susceptibility test of the methanolic leaf extract of $A$. hispidum

\begin{tabular}{|c|c|c|c|c|c|c|c|c|c|c|c|}
\hline \multirow[b]{2}{*}{$\begin{array}{c}\text { Exract/drug conc. } \\
\mathrm{mg} / \mathrm{ml}\end{array}$} & \multicolumn{11}{|c|}{ Micro organisms/Diameter of zones of inhibition (mm) } \\
\hline & $\begin{array}{l}\text { Staph. } \\
\text { aureus }\end{array}$ & $\begin{array}{c}\text { Strep. } \\
\text { Pyogene }\end{array}$ & $\begin{array}{c}\text { Con. } \\
\text { bacterium } \\
\text { specie }\end{array}$ & $\begin{array}{l}\text { Bacillus } \\
\text { Subtilis }\end{array}$ & $\begin{array}{c}\text { Salmo nella } \\
\text { typhi }\end{array}$ & $\begin{array}{c}\text { Klebsiella } \\
\text { Pnumoniae }\end{array}$ & $\begin{array}{c}\text { Pseudo monas } \\
\text { aeruginosa }\end{array}$ & E. coli & $\begin{array}{l}\text { Asper } \\
\text { gillus } \\
\text { niger }\end{array}$ & $\begin{array}{l}\text { Penici } \\
\text { llium specie }\end{array}$ & $\begin{array}{c}\text { Con. } \\
\text { Albican }\end{array}$ \\
\hline 200 & $7.00 \pm 1.00$ & $\mathrm{R}$ & $14.50 \pm 0.50$ & $7.07 \pm 1.07$ & $\mathrm{R}$ & $7.93 \pm 0.12$ & $9.67 \pm 1.53$ & $\mathrm{R}$ & $\mathrm{R}$ & $\mathrm{R}$ & $\mathrm{R}$ \\
\hline 400 & $8.66 \pm 0.58$ & $\mathrm{R}$ & $18.33 \pm 0.58$ & $9.00 \pm 0.00$ & $\mathrm{R}$ & $8.53 \pm 0.50$ & $14.33 \pm 0.58$ & $\mathrm{R}$ & $\mathrm{R}$ & $\mathrm{R}$ & $\mathrm{R}$ \\
\hline 600 & $10.00 \pm 1.00$ & $\mathrm{R}$ & $21.33 \pm 0.58$ & $9.67 \pm 1.53$ & $\mathrm{R}$ & $10.67 \pm 0.58$ & $14.00 \pm 1.00$ & $\mathrm{R}$ & $\mathrm{R}$ & $\mathrm{R}$ & $\mathrm{R}$ \\
\hline 800 & $11.00 \pm 0.00$ & $\mathrm{R}$ & $23.67 \pm 1.53$ & $11.67 \pm 0.58$ & $\mathrm{R}$ & $12.00 \pm 0.00$ & $16.00 \pm 1.00$ & $\mathrm{R}$ & $\mathrm{R}$ & $\mathrm{R}$ & $\mathrm{R}$ \\
\hline 1000 & $12.20 \pm 1.06$ & $\mathrm{R}$ & $24.00 \pm 1.00$ & $13.00 \pm 1.00$ & $\mathrm{R}$ & $13.33 \pm 1.15$ & $18.23 \pm 1.08$ & $\mathrm{R}$ & $\mathrm{R}$ & $\mathrm{R}$ & $\mathrm{R}$ \\
\hline *250 mg (TTC) & $23.33 \pm 0.58$ & $23.00 \pm 1.00$ & $27.23 \pm 0.68$ & $22.17 \pm 0.77$ & $22.00 \pm 1.00$ & $20.27 \pm 0.64$ & $23.00 \pm 1.00$ & $27.23 \pm 0.68$ & $0.70 \pm 1.54$ & $21.00 \pm 1.00$ & $20.07 \pm 1.05$ \\
\hline
\end{tabular}

Key: $\mathrm{R}=$ Resistant (i.e not sensitive), TTC $=$ Tetracycline, $*=$ standard drug $(2.5 \times 105 \mu \mathrm{g} /$ disc $)$, Data are presented as means \pm S.D and $n=3$.

Table 3. The minimum inhibitory concentration (MIC) values of some organisms to the methanolic extract of $A$. hispidum

\begin{tabular}{cccccc}
\hline \multirow{2}{*}{ Bacteria } & \multicolumn{5}{c}{ Extract Concentrations (mg/ml) } \\
\cline { 2 - 6 } & 12.5 & 25 & 50 & 100 & 200 \\
\hline Conynebacterium species & + & $\beta$ & - & - & - \\
Pseudomonas aeruginosa & + & + & $\beta$ & - & -
\end{tabular}

Key: - = No growth (inhibition of bacterial growth); $+=$ There was growth (Resistant); $\beta=$ Least concentration showing no turbidity (MIC).

Table 4. The Minimum Bactericidal Concentration (MBC) of some organism to the methanolic extract of $A$. hispidum

\begin{tabular}{cccccc}
\hline Bacteria & \multicolumn{5}{c}{ Extract Concentration (mg/ml) } \\
\cline { 2 - 6 } & 12.5 & 25 & 50 & 100 & 200 \\
\hline Conynebacterium species & + & + & + & - & - \\
Pseudomonas aeruginosa & + & + & + & $\beta$ & + \\
\hline
\end{tabular}

Key: - = No growth; $+=$ There was growth; $\beta=$ Minimum bactericidal concentration (MBC).

\section{Discussion}

Previous research in to the phytochemistry of the leaves of Acanthospermum hispidum revealed the presence of flavonoids, cardiac glycosides, alkaloids, terpenes, saponins, carbohydrates and tannins, while steroids, amino acid and Phlobatanins were absent (Harekrishna et al., 2010). These secondary metabolites are responsible for most physiological and chemotherapeutic effects exhibited by plant extractives both in vitro and vivo (Usman, 2012). The extract under study had shown the presence of tannins and flavonoids; these phytochemicals had been known to inhibit the growth of microorganisms (Havagiray et al., 2004; Ogundaini, 2005; Usman et al., 
2007; Usman, 2012).

Alkaloids in the extract under study produce analgesic, anti-inflamatory and adaptogenic effects which help to develop resistance against diseases and endurance against stress (Gani, 1990; Gupta, 1994; Aska, 2008).

Carbohydrates in this extract occupy an important position in metabolism so the method of their detection is useful in phytochemistry. Carbohydrates have no therapeutic actions but they possibly increase the effectiveness of the biological active principles in the plant, thus most therapeutic principles isolated from plants occur in combination with sugar as glycosides (Iwu, 1984; Vollekowa et al., 2001).

In vitro disc diffusion method was used to study the antimicrobial activity of methanol leaf extract. The microorganisms tested in the study are widely distributed in air, water, faeces and can contaminate our food, thus producing enterotoxin which leads to some infections of the gastrointestinal tract including diarrhoea (Lucas and Gilles, 2003). The result of the antimicrobial activity on some bacterial pathogens shows that the extract at various concentrations inhibited the growth of Staphylococcus aureus Conynebacteria sp. Bacillus subtilis, Klebsiella pnumoniae and Pseudomonas aeruginosa were presented in Table 2, but there was no activity against Streptococcus pyogenes, E. coli, Salmonella typhii, Candida albicans, Aspergillus niger and Pencillium species. The result obtained showed that methanolic leaf extract of Acanthospermum hispidum exhibited inhibitory activities against some microorganisms tested at varying degrees of concentration as demonstrated by the diameters of the zones of inhibitions. These result where in conformity with those earlier reported by Harekrishna et al. (2010) and Chakraborty et al. (2012). The ability of the extract to inhibit the growth of these organisms in vitro may be due to the presence of some active chemical constituents found in the extract (Ogundaini, 2005).

The MIC/MBC data obtained from the evaluation of CMLE against the tested organisms ranges from $25 \mathrm{mg} / \mathrm{ml}$ to $50 \mathrm{mg} / \mathrm{ml}$ and $50 \mathrm{mg} / \mathrm{ml}$ to $100 \mathrm{mg} / \mathrm{ml}$ respectively, shown in Table 3 and 4 . There is a need to consider the use of this leaf extract that have shown some measures of antimicrobial activities, judging by the antimicrobial activity, low Minimum Inhibitory Concentration (MIC) and low Minimum Bactericidal Concentration (MBC) on tested microorganisms.

\section{Conclusion}

In conclusion, the extract was found to be effective against the tested pathogenic microorganisms at varying concentrations. Therefore, this study validates the use of the leaf of Acanthospermum hispidum traditionally in some parts of Northern Nigeria.

\section{Acknowledgments}

The authors gratefully acknowledge the technical assistance of Mr. Fine Akawu of Chemistry Department, University of Maiduguri, Maiduguri.

\section{References}

Adu, F., Gbedema, S. Y., Akanwariwiak, W. G., Annan, K., \& Boamah, V. E. (2011). The Effects of Acanthospermum hispidum extract on the antibacterial activity of amoxicillin and ciprofloxacin. Hyegeia. $J$. D. Med, 3(1), 58-63.

Awe, I. S., \& Sodipo, O. A. (2001). Purification of saponnins of roots of Blighia sapida KOENLG-HOLL. Nig. J. Biochem. Med, 16(37), 201-204.

Bello, C. S. S. (2002). Laboratory Manual for students of Medical Microbiology (p. 113) Satographics press, Jos, Plateau State Nigeria.

Cheesbrough, M. C. (2004). District Laboratory Practice in Tropical Countries Part 2: (pp. 133-147). Cambridge University Press U.K.

Chukruborty, A. K., Gaikward, A. V., \& Singh, K. B. (2012). Phytopharmacological review on A. hispidum. J. Appl. Pharm. Sci, 2(03), 144-148.

Deepa, N., Rajendra, N. N., Lata, T., \& Jagannathan, N. S. (2004). Antibacterial and anti-fungal activities of ethyl acetate extract and the isolated fraction of Acanthospermum hispidum DC. Journal of Natural Remedie, 4(2), 90-194.

Edewor, T., \& Olajire, A. (2011). Two Flavones from Acanthospermum hispidum DC and Their Antibacterial Activity. International Journal of Organic Chemistry, 1(3), 132-141. http://dx.doi.org/10.4236/ijoc.2011.13020

Evans, W. C. (2002). Trease and Evans Phamacognosy. (15th ed., p. 585) China: Harcourt Publishers Ltd. 
Faleye, F. J., Odeyemi, A. T., \& Aderogba, A. A. (2012). Evaluation of the Chemical Composition and Antimicrobial activities of three Nigerian medicinal plants. Elixir Appl. Biology, 45, 7652-7656.

Finar, I. L. (2005). Organic Chemistry Sterochemistry and the Chemistry of Natural Products. (5th ed., pp. 705-805). Pearson, Singapore.

Gani, B. (1990). Antidiarrhoeal activity of methanolic extract from Helianthemum glomeration Lag and Rubus corrifolius Focke in suding mice. J. Ethnopharmacol, 108(3), 395-397.

Gupta, S. S. (1994). Prospects and perspectives of natural plant products. Indian J. Pharm, 26, 1-10.

Havagiray, R., Ramesh, C., \& Sadhna, K. (2004). Study of antidiarrhoeal activity of Calotropis gigantean R.B.R in experimental animals. J. Pharm. Sc, 7, 70-75.

Harbone, L. (1973). Phyotochemical Methods: A Guide to Mode rn Techniques of Plant Analysis (p. 279). Chapman A and Hall. London.

Harbone, L. (1998). Phyotochemical Methods: A Guide to Modern Techniques of Plant Analysis. (3rd ed., pp. 1-301). London: Chapman A and Hall.

Harekrishna, R., Anup, C., Setyabrata, B., Bhabani, S. N., \& Sruti, R. M. (2010). Preliminary phytochemical investigation and anthelmintic activities Acanthospermum hispidum DC. J. Pharm. Sc. and Technology, 2(5), 217-221.

Holm, L., Del, Y., Holm, E., Panclon, T., \& Herberger, T. (1997). World Weed Natural Histories and Distributions (p. 245). John Wiley and Sons inc.New York.

Lamikanra, A. A. (1999). Essential Microbiology (2nd ed., pp. 125-131, 304) AMKRA Books 8. Obokun St. Ilupeju Estate, Lagos, Nigeria.

Lucas, A. O., \& Gilles, H. M. (2003). A Short Textbook on Public Health Care Medicine of the Tropics (4th ed., pp. 49-65) London: Hodder Headline Group.

Musa, A. M., Abbas, G., Aliyu, A. B., Abdullahi, M. S., \& Akpula, I. N. (2008). Phytochemical and antimicrobial screening of Indigofera Gillert (Papilionaceae). Res. J. Med. Plts, 2(2), 74-78. http://dx.doi.org/10.3923/rjmp.2008.74.78

Ogundaini, A. O. (2005). A Text Book of Medicinal Plants from Nigeria. (pp. 10-11). University of Lagos Press Nigeria.

Olajide, O. O., Oladosu, A. I., \& Christianah, O. F. (2014). Tetrahydroanthracene Derivative: Anti-microbial Isolate from Acanthospermum hispidum DC. International Journal of Advanced Chemistry, 2(2), 182-184. http://dx.doi.org/10.14419/ijac.v2i2.3519

Reynold, J. E. (1989). The Extrapharmacopocia, (29th ed., pp. 646-660). London: The pharmaceutical press,

Sodipo, O. A., Abdulrahman, F. I., Alemika, T. E., Gulani, I. A., \& Akinniyi, J. A. (2010). Gas chromatography-mass spectroscophy (GC-MS) analysis and antimicrobial investigation of the ethyl acetate extract of "Gorongo" Solanum macrocarpum L. J. Pharm. Biores, 7(2), 164-172.

Sodipo, O. A., Abdulrahman, F. I., Alemika, T. E., \& Gulani, I. A. (2012). Separation, purification, isolation, identification and antimicrobial properties of the ethanolic fruit extract "Gorongo" Solanum marcrocarpum L. Int. J. Anal. Pharm. Biomed.Sci, 1(1), 30-38.

Sofowora, A. (2008). Medicinal and Traditional Medicine in Africa (3rd ed., p. 436). Spectrum Books. Ltd.

Smith, N. M. (2002). Weeds of the Wet/dry tropics of Australia-a field guide (p. 112). Envirommental Centre NT, Inc.

Usman, H. (2012). Studies of the phytochemical contents and antimicrobial activities of the stem bark of Bauhinia rufecens LAM (Leguminosae Caesalpinoldaea), Ph D. Thesis, University of Maiduguri (p. 249). Maiduguri, Nigeriria.

Usman, H., Abdulrahman, F. I., \& Ladan, A. A. (2007). Phytochemical and antimicrobial evaluation of Tribulus terrestris L. (Zygophylaceae) growing in Nigeria. Res. J. Bio.Sci, 2(3), 244-248.

Vlietinek, J. A., Van Hoof, L., Totte, J., Lasure, A., Vanden Berghe, D., Rwangabo, P. C., \& Mrukyunmwami, J. (1995). Sceening of hundred Rwandes medicinal plants for antimicrobial and antiviral properties. $J$. Ethanopharmacol, 46, 31-47. http://dx.doi.org/10.1016/0378-8741(95)01226-4 
Vollekowa, A., Kostalova, D., \& Sochorova, R. (2001). Isoquinoliniia microbioline alkaloids from Mahania aquifolium stem bark is active against Mulassezia spp. Folia, 46, 107-111. http://dx.doi.org/10.1007/BF02873586

Zimmer, D. E., Pederaon, M. W., \& Maquire, C. E. (1967). A Bioassay for alfafa saponnins using fungus $\begin{array}{llllll}\text { Tricodemu virile } & \text { pers. } & \text { Crop } & \text { 223-225. }\end{array}$ http://dx.doi.org/10.2135/cropsci1967.0011183X000700030015x

\section{Copyrights}

Copyright for this article is retained by the author(s), with first publication rights granted to the journal.

This is an open-access article distributed under the terms and conditions of the Creative Commons Attribution license (http://creativecommons.org/licenses/by/3.0/). 